\title{
Effect of foliar application of micronutrients on ginger productivity
}

\author{
Nagarajappa Adivappar \& M K Naik \\ University of Agricultural and Horticultural Sciences, Shivamogga - 577204, Karnataka. \\ *E-mail: nagarajappaadivappar@uahs.edu.in
}

Received 31 July 2021; Revised 14 October 2021; Accepted 27 October 2021

\begin{abstract}
Ginger (Zingiber officinale Rosc) is cultivated in different agro-climatic zones of Karnataka. Correction of deficiency of nutrients through foliar application of micronutrients is imperative to maintain the growth and development of the crop. Hence, large scale demonstrations were conducted and the impact analysis of crop specific ICAR-Indian Institute of Spices Research, Kozhikode-micronutrient formulation (released as "Ginger Special") on productivity and profitability of ginger in Southern Transitional Zone of Karnataka was carried out during 201619 by involving 429 farmers in an area of 133.20 ha. Foliar application of ginger special $\left(5 \mathrm{gl}^{-1}\right)$, 45 days after planting up to six months at an interval of 45 days showed significant increase in fresh yield (23.94 $\left.\mathrm{t} \mathrm{ha}^{-1}\right)$, higher returns ha-1 (Rs.9,80,300) and higher BCR (2.89). The test farmers who used ginger special obtained a mean additional fresh yield ( $\left.2.44 \mathrm{t} \mathrm{ha}^{-1}\right)$, additional return (Rs. 99,500 ha-1) besides providing additional employment to the farm workers (12 ha $\left.{ }^{-1}\right)$. Use of ginger special, created a good impact on productivity and profitability of ginger cultivation and the technology has spread in an area of 500 ha in Shivamogga district of Karnataka.
\end{abstract}

Keywords: ginger special micronutrient, productivity, impact, nutrient formulation

Ginger (Zingiber officinale Rosc.), an important spice and medicinal crop is cultivated in different states of India. It is used as fresh as well as in processed forms. In Karnataka, traditionally it is cultivated in different types of soils in Southern transitional zone (parts of Hassan, Shivamogga, Chikkamagalur districts), hilly zone (parts of Hassan, Shivamogga, Chikkamagalur, Coorg districts), and coastal zones (Dakshina Kannada, Uttara Kannada \& Udupi). The salient features of ginger growing red and red loamy soils of Southern Transitional Zone are: acidic to neutral (5.5-7.0), normal electric conductivity

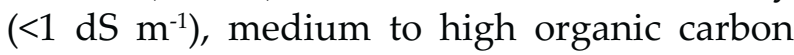
content $(0.5-1.0 \%)$, deficient in micronutrients viz., Zn (0.4-0.6 ppm) and boron (0.3-0.4 ppm). Due to the deficiency of nutrient content in the soil, foliar application of micronutrients is imperative to maintain the plant health to get higher yield. Foliar application provides low quantum of application of nutrients, uniform 
distribution within the plant, easiest method, quick utilization of nutrients and permits the correction of observed deficiencies in less time compared to soil application (Fageria et al. 2009). In Shivamogga district, ginger is cultivated in an area of 3828 ha with a production of 38403 tonnes and productivity of $10.03 \mathrm{t} \mathrm{ha}^{-1}$ (Anonymous, 2018). We report here the result of large scale demonstrations conducted on the use of "ginger special" on the yield and productivity of ginger.

During 2016-17 four training programmes on scientific cultivation of ginger were conducted by involving 153 ginger growers before conducting large scale demonstrations. During the problem analysis, it was noticed thatmajority of the plants expressed deficiency symptoms, which resemble the symptoms of $\mathrm{K}, \mathrm{Mg}, \mathrm{Zn}$ and B. The soils of Southern Transitional Zone of Karnataka are deficient in zinc and boron which act as limiting factor for growth and development of ginger. Hence, it was decided to conduct large scale demonstrations on foliar application of "ginger special" on ginger plants as one of the components under the ginger project. The implementation area comprised of three taluks of Shivamogga district in Southern Transitional Zone of Karnataka. From 2016-17 to $2018-19,429$ demonstrations were conducted in an area of 133.20 ha by involving 429 farmers. The ginger cultivar 'Himachal' was selected due to larger area and sowing was taken up in the month of March under irrigated condition and harvested after maturity. The farmers were advised to use "IISR-Ginger Special" $0.5 \%$ as foliar spray, 45 days after planting up to six months (four sprays at an interval of 45 days). This was developed by ICAR-Indian Institute of Spices Research, Kozhikode, India and it consists of potassium (200-500 $\left.\mathrm{mg} \mathrm{L}^{-1}\right)$, magnesium (50-150 mg L-1), zinc (200-350 mg $\mathrm{L}^{-1}$ ) and boron (100-300 $\mathrm{mg} \mathrm{L}^{-1}$ ). The mean yield of demonstration plots from 45 farmers (15 farmers taluk ${ }^{-1}$ ) was collected for three years in both plots treated with "ginger special" as foliar application and without application of the "ginger special" and keeping all other practices constant as per the package of practices of University of Horticultural Sciences, Bagalkot (Anonymous, 2013). Paired ' $t$ '-test was used to compare the means of "ginger special" treated versus untreated. The total cost, total returns and $\mathrm{B}: \mathrm{C}$ ratio were calculated according to the prevailing market rates of respective years.

During 2016-17, 2017-18 and 2018-19 demonstrations were conducted in an area of 37.60 ha, 27.20 ha and 64.40 ha by involving 94, 90 and 245 farmers respectively, who were growing ginger cv. Himachal. Foliar application of ginger special $(0.5 \%)$ has showed marked increase in fresh yield $\left(\mathrm{t} \mathrm{ha}^{-1}\right)$, higher returns $\mathrm{ha}^{-1}$ and higher $\mathrm{B}: \mathrm{C}$ ratio. Use of "ginger special" resulted in significantly $(p<0.01)$ higher fresh yields up to $23.94 \mathrm{t} \mathrm{ha}^{-1}$ (11.35\%), $25.02 \mathrm{t} \mathrm{ha}^{-1}(12.45 \%)$ and $22.85 \mathrm{t} \mathrm{ha}^{-1}$ (10.12\%) compared to without the foliar spray of ginger special i.e., $21.50,22.25$ and $20.75 \mathrm{t} \mathrm{ha}^{-1}$ fresh yield during the three consecutive years. Overall 11.33\% higher yield was recorded with application of ginger special (Table 1). Since the soils of the demonstration area are deficient in micronutrients viz., zinc (0.4-0.6 ppm), boron (0.3-0.4 ppm) and medium content of available potassium (144-336 kg ha-1), response to foliar application of ginger special is obvious. Increase in yield could be attributed to the timely supply of potash, magnesium, boron and zinc. Magnesium and zinc are effective in regulation of plant growth. Foliar nutrition usually penetrates the cuticle of the leaf or stomata, enter the cells rapidly and fulfil the nutrient demand of the growing plant and thus ameliorate nutrient deficiencies (Devi \& Shanthi, 2013). Roy et al. (1992) documented maximum yield of ginger due to combined application of $\mathrm{Zn}(0.3 \%)+\mathrm{Fe}(0.2 \%)+\mathrm{B}(0.2 \%)$ twice at 45 and 75 days after planting. Similar results were also documented by Tamilselvi et al. (2002) and Babaeian et al (2011) owing to the use of micronutrients in different crops. Bose et al. (2008) reported that inclusion of sulphur and magnesium in nutrition enhanced the fresh 
Table 1. Effect of ginger special on productivity of ginger cv. Himachal

\begin{tabular}{llllllll}
\hline Year & $\begin{array}{l}\text { Number } \\
\text { of farmers } \\
\text { participated }\end{array}$ & $\begin{array}{l}\text { Total area } \\
\text { covered } \\
(\text { ha) }\end{array}$ & $\begin{array}{l}\text { Mean fresh } \\
\text { yield without } \\
\text { use of ginger } \\
\text { special }\left(\mathrm{t} \mathrm{ha}^{-1}\right)\end{array}$ & $\begin{array}{l}\text { Mean fresh yield } \\
\text { with the use of } \\
\text { ginger special @ } \\
5 \mathrm{~g} \mathrm{~L}^{-1} \text { for 4 times } \\
\left(\mathrm{t} \mathrm{ha}^{-1}\right)\end{array}$ & $\begin{array}{l}\text { Per cent } \\
\text { increase in } \\
\text { yield }\end{array}$ & z-statistic SE & \\
\hline $2016-17$ & 94 & 37.60 & 21.50 & 23.94 & 11.35 & $6.22^{* *}$ & 0.39 \\
$2017-18$ & 90 & 27.20 & 22.25 & 25.02 & 12.45 & $5.52^{* *}$ & 0.52 \\
$2018-19$ & 245 & 68.40 & 20.75 & 22.85 & 10.12 & $9.22^{* *}$ & 0.29 \\
Total & 429 & 133.20 & 21.50 & 23.94 & 11.33 & $10.61^{* *}$ & 2.14 \\
Mean & & & & & & & \\
\hline
\end{tabular}

Note: ${ }^{* *}$ indicates level of significance at 0.01

yield of turmeric in depleted red lateritic soils. With respect to profitability, higher returns ha-1 (Rs. 718200, Rs.1125900, Rs.1096800) and higher benefit cost ratio $(2.35,3.34$ and 2.92$)$ were recorded by growers who used consecutively for three years compared to those who did not use the "ginger special" (Table 2). Similar results were also reported by Jegadeeshwari et al. (2018) through foliar application of micronutrient formulation (ICAR-IIHR:banana special) on banana.The results presented in Table 3 indicates the socio-economic impact of the "ginger special" that reflect the mean additional yield $\left(2.44 \mathrm{t} \mathrm{ha}^{-1}\right)$, additional return (Rs. 99500 ha $^{-1}$ ) and additional man-days (12 ha$\left.{ }^{1}\right)$. The socio-economic impact of the study was observed in terms of additional employment generation which indicated 12 additional man-

Table 2. Influence of ginger special on profitability of ginger cv. Himachal

\begin{tabular}{|c|c|c|c|c|c|c|c|}
\hline Year & $\begin{array}{l}\text { Mean market } \\
\text { rate/tonne } \\
\text { (Fresh) }\end{array}$ & $\begin{array}{l}\text { Total returns } \\
\text { without use } \\
\text { of ginger } \\
\text { special ha-1 } \\
\text { (Rs.) }\end{array}$ & $\begin{array}{l}\text { Total returns } \\
\text { with use } \\
\text { of ginger } \\
\text { special ha-1 } \\
\text { (Rs.) }\end{array}$ & $\begin{array}{l}\text { Total cost } \\
\text { without } \\
\text { use of } \\
\text { ginger } \\
\text { special ha-1 } \\
\text { (Rs.) }\end{array}$ & $\begin{array}{l}\text { Total cost } \\
\text { with use } \\
\text { of ginger } \\
\text { special ha-1 } \\
\text { (Rs.) }\end{array}$ & $\begin{array}{l}\text { B:C ratio } \\
\text { (without } \\
\text { ginger } \\
\text { special) }\end{array}$ & $\begin{array}{l}\text { B:C ratio } \\
\text { (with } \\
\text { ginger } \\
\text { special) }\end{array}$ \\
\hline 2016-17 & 30000 & 645000 & 718200 & 287500 & 305000 & 2.24 & 2.35 \\
\hline 2017-18 & 45000 & 1001250 & 1125900 & 318750 & 337250 & 3.14 & 3.34 \\
\hline 2018-19 & 48000 & 996000 & 1096800 & 355000 & 375000 & 2.81 & 2.92 \\
\hline Mean & 41000 & 880750 & 980300 & 320417 & 339083 & 2.75 & 2.89 \\
\hline
\end{tabular}

Table 3. Change in yield and net returns of ginger with the use of ginger special

\begin{tabular}{llllll}
\hline Year & $\begin{array}{l}\text { Additional } \\
\text { yield ha }{ }^{-1}\end{array}$ & $\begin{array}{l}\text { Additional } \\
\text { cost ha }{ }^{-1}\end{array}$ & $\begin{array}{l}\text { Additional } \\
\text { net return ha }\end{array}$ & $\begin{array}{l}\text { Ratio of additional } \\
\text { cost to additional } \\
\text { return }\end{array}$ & $\begin{array}{l}\text { Additional employment } \\
\text { generation (man days ha }\end{array}$ \\
\hline $2016-17$ & 2.44 & 17500 & 73200 & 4.18 & 12 \\
$2017-18$ & 2.77 & 18500 & 124650 & 6.74 & 12 \\
$2018-19$ & 2.10 & 20000 & 100800 & 5.04 & 12 \\
Mean & 2.44 & 18667 & 99550 & 5.33 & 12 \\
\hline
\end{tabular}


days ha-1 for spraying "ginger special". During the three years of demonstration, employment generation to the extent of 1598 additional mandays was created for foliar spray of "ginger special".

Ginger being a soil exhaustive crop responds well for the foliar nutrition. The foliar application of ginger special $(0.5 \%)$, a commercial product from ICAR-IISR, Kozhikode, 45 days after planting up to six months at an interval of 45 days resulted in mean additional yield of $2.44 \mathrm{t} \mathrm{ha}^{-1}$ and additional return of Rs. $99500 \mathrm{ha}^{-1}$. In the demonstrational area, Rs.1.32 crores additional returns and 1320 additional mandays were generated. The technology has spread to an area of 500 ha of ginger.

\section{Acknowledgement}

Authors are thankful to the Deputy Director, Shivamogga, Karnataka State Department of Horticulture and Director of Research, University of Agricultural and Horticultural Sciences, Shivamogga for providing financial assistance.

\section{References}

Anonymous 2013 Package of Practices Recommendations. Directorate of Extension, University of Horticultural Sciences, Bagalkot, Karnataka.

Anonymous 2018 Statistics of area and production of horticulture crops of Shivamogga district, Karnataka https://shimoga.nic.in/ en/horticulture-department/ accessed on 22.04.2020.
Babaeian M, Piri I, Tavassoli A, Esmaeilian Y \& Gholami H 2011 Effects of foliar micronutrient application on osmotic adjustments, grain yield and yield components in sunflower (Alstar cultivar) under water stress at three stages. African J. Agri. Res. 6: 1204-1208.

Bose P, Sanyal D \& Majumdar K 2008 Balancing sulfur and magnesium nutrition for turmeric and carrot grown on red lateritic soil (East Zone, India). Better Crops. 92: 23-25.

Devi N D \& Shanthi A 2013 Effect of foliar spray of water soluble fertilizer on growth and NPK uptake of chilli hybrid (Capsicum annuum L.). Asian Hort. 8: 222-225.

Fageria N K, Filho M P, Barbosa, Moreira A \& Guimarãe C M 2009 Foliar fertilization of crop plants. J. of Plant Nutrition. 32: 1044-1064.

Jegadeeswari D, Dheebakaran, G A \& Paul Pandi V K 2018 Foliar application of micronutrients for enhancing productivity of banana under irrigated conditions through farmers' participatory approach. Int. J. of Chemical Stud. 6: 1094-1097.

Roy A, Chatterjee R, Hassan A \& Mitra S K 1992 Effect of $\mathrm{Z}, \mathrm{N}, \mathrm{Fe}$, and $\mathrm{B}$ on growth, yield and nutrient content in leaf of ginger. Indian Cocoa Arecanut Spices J. 15: 99-101.

Tamilselvi P, Vijayakumar, R M \& Naina P 2002 Studies on the effect of foliar application of micronutrients on growth and yield of tomato (Lycopersicon esculentum Mill) CV. PKM-1. South Indian Horticulture. 53: 46-55. 